\title{
Self-mutilation of teeth due to peer pressure: an aspect of child psychology
}

\author{
Anuradha Agrawal, ${ }^{1}$ Saurabh Kumar Gupta, ${ }^{2}$ Payal Saxena, ${ }^{2}$ Shubham Agrawal ${ }^{3}$
}

${ }^{1}$ Department of Paediatric Dentistry, Government College of Dentistry, Indore, Madhya Pradesh, India

${ }^{2}$ Department of Conservative Dentistry \& Endodontics,

Government College of Dentistry, Indore, Madhya Pradesh, India

${ }^{3}$ Department of Orthodontics, Modern Dental College \& Research Centre, Indore, Madhya Pradesh, India

\section{Correspondence to} Dr Saurabh Kumar Gupta, payal.endo@gmail.com

Accepted 23 May 2014

\section{DESCRIPTION}

An 11-year-old boy was brought by his parents for cold-sensitive teeth resulting from a self-inflicted grinding injury to his upper anterior teeth. On examination, proclined maxillary incisors, incompetent lips and a class II molar relationship were evident. A horizontal ' $v$ '-shaped notch on the facial surface, located at the junction of the middle and incisal third of the maxillary central incisors, was present. The groove was shallow in the distal margin and gradually deepened as it approached the mesial margin of the central incisors with dentine involvement starting from the mid-facial region. The maxillary left lateral incisor also had a less severe but similar condition (figures 1 and 2).

The shy and introverted boy was non-cooperative and reluctant to give a proper history.

On being asked the reason for his actions, the boy replied that his peers at school would make fun of him because of his large teeth, which led him to grind them, in the hope that they would become normal in size; however, the resulting

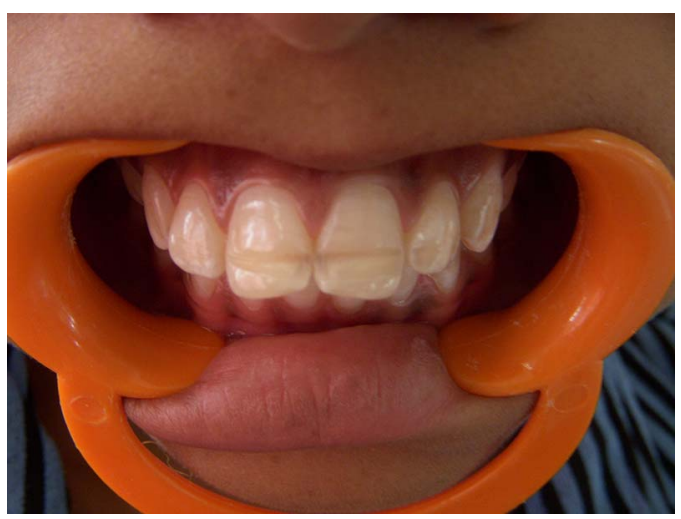

Figure 1 Patient with self-damaged maxillary incisors.

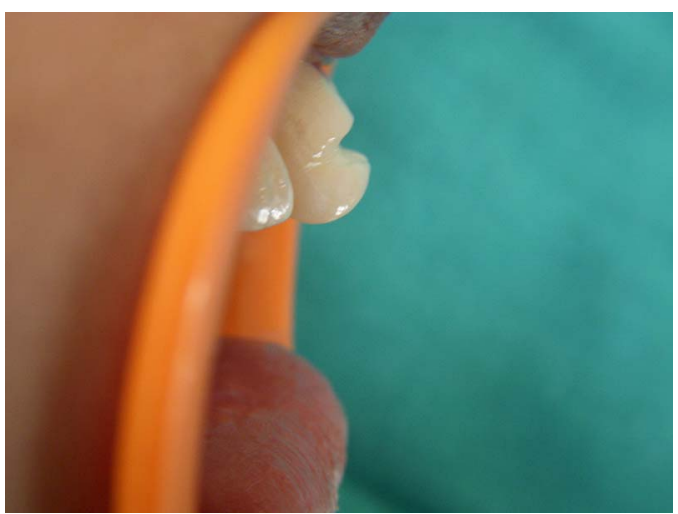

Figure 2 Lateral aspect of the incisor showing the depth of the destroyed tooth.

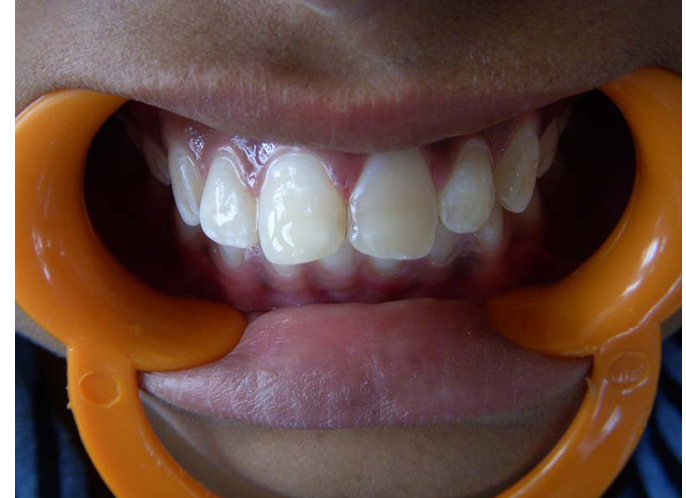

Figure 3 Damaged area of the teeth restored with light cure composite resin.

sensitivity and pain made him seek help. His father asked his son's close friends if they knew of anyone who had suggested to him to grind his teeth, but they replied in the negative.

The defect was restored with light cure composite resins (figure 3 ) and orthodontic treatment was advised, which the family refused.

The child's psychological assessment was performed by a child psychologist who reported that the patient was mentally normal with average intelligence and a low confidence level. It was felt that the impact of teasing by the boy's peers, as well as lack of proper communication with his parents and the psychological requirement of social approval regarding dental beauty, had probably been responsible for the boy's actions. The child and his parents were given proper counselling.

This report depicts the impact that peers have on the mind of a growing child. The influence exerted on the thinking and behavioural patterns of adolescents by those close to them is remarkable $e^{1}$; it is governed not only by relatives but also by friends and close acquaintances.

\section{Learning points}

- The role of peers on a child's psychology and behaviour is remarkable.

- Class II type-I molar relation frequently leads to protruded maxillary incisors. Proper involvement and guidance should be given by parents to children with proclined incisors.

- Proper psychological counselling must be offered at the right time to such children and their parents. Appropriate intervention and correction of skeletal and/or dental variation in early stages leads to improved results. 
Contributors AA saw the patient in the paediatric dentistry clinic, and discussed the case with SKG; they treated the patient and also counselled him. PS and SA reviewed the literature and wrote the article.

Competing interests None.

Patient consent Obtained.
Provenance and peer review Not commissioned; externally peer reviewed.

\section{REFERENCES}

1 Reijntjes $\mathrm{A}$, Kamphuis $\mathrm{JH}$, Prinzie $\mathrm{P}$, et al. Peer victimization and internalizing problems in children: a meta-analysis of longitudinal studies. Child Abuse Negl 2010;34:244-52

Copyright 2014 BMJ Publishing Group. All rights reserved. For permission to reuse any of this content visit

http://group.bmj.com/group/rights-licensing/permissions.

BMJ Case Report Fellows may re-use this article for personal use and teaching without any further permission.

Become a Fellow of BMJ Case Reports today and you can:

- Submit as many cases as you like

- Enjoy fast sympathetic peer review and rapid publication of accepted articles

- Access all the published articles

- Re-use any of the published material for personal use and teaching without further permission

For information on Institutional Fellowships contact consortiasales@bmjgroup.com

Visit casereports.bmj.com for more articles like this and to become a Fellow 